\title{
Adhesion of human Lactobacillus acidophilus strain LB to human enterocyte-like Caco-2 cells
}

\author{
Gilles Chauvière, Marie-Hélène Coconnier, Sophie Kernéis, Jacky Fourniat and \\ Alain L. Servin*
}

Equipe de Pathogènie Microbienne Moléculaire Intestinale, Département de Microbiologie et Immunologie, Université Paris XI, UFR de Sciences Pharmaceutiques, 92296 Châtenay-Malabry, France

(Received 29 November 1991; revised 13 April 1992; accepted 13 May 1992)

\begin{abstract}
Twenty-five strains of lactobacilli were tested for their ability to adhere to human enterocyte-like Caco- 2 cells in culture. Seven Lactobacillus strains adhered well to the Caco- 2 cells, of which three possessed calcium-independent adhesion properties. A high level of calcium-independent adhesion was observed with the human stool isolate Lactobacillus acidophilus strain LB. Scanning electron microscopy revealed that this strain adhered to the apical brush border of the cells. Adhesion increased in parallel with the morphological and functional differentiation of the Caco-2 cells. Two Lactobacillus components were involved in this adhesion. One was protease-resistant and bacterial-surface-associated; the other was heat-stable, extracellular and protease-sensitive.
\end{abstract}

\section{Introduction}

Lactobacilli are important in controlling undesirable microflora in the intestinal and uro-genital tracts of humans and animals. Some lactobacilli adhere to freshly isolated uro-epithelial cells (Chan et al., 1984, 1985; Reid \& Sobel, 1987) and living adhering lactobacilli or cellwall fragments possess inhibiting properties against adhesion of uro-pathogenic Escherichia coli (Chan et al., 1985; Reid et al., 1987). Contradictory results have been obtained for the gastrointestinal tract (reviewed by Conway, 1988). Recently, using Caco- 2 cells as an intestinal cell model, we have reported an inhibition of diarrheagenic Escherichia coli adhesion by the human L. acidophilus strain LB (Chauvière et al., 1992). However, little is currently known about the mechanism of adhesion of lactobacilli to human intestinal cells (Conway, 1988; Reid et al., 1990). Kleeman \& Klaenhammer (1982) screened 27 human Lactobacillus isolates and reported that four L. acidophilus strains, BG2FO4, MSO1, MSO2 and MSO4 adhered specifically, in a calcium-independent manner, to human fetal intestinal epithelial cells. Conway et al. (1987) reported the adhesion of strain ADH to human colonic cells. Hood \& Zottola (1989) observed that the cells of strain BG2FO4 closely associate with the brush border of the human intestinal cell line HITC FHs0074 (ATCC CCL 241).

* Author for correspondence. Fax 146831303.
Recently Elo et al. (1991) reported that the Lactobacillus case $i$ strain GG adheres to Caco- 2 cells.

To gain further understanding of the mechanisms by which lactobacilli adhere to human intestinal cells, we studied the adhesion of a large number of Lactobacillus strains to enterocyte-like Caco-2 cells in culture. Bacterial attachment to the cell surfaces was characterized quantitatively by light and electron microscopic examination. Using the highly adhering strain LB, the adhesive determinants involved in adhesion were partially characterized. Moreover, since Caco- 2 cells spontaneously differentiate in culture, the expression of Lactobacillus binding sites during the differentiation process was investigated.

\section{Methods}

Bacterial strains. The human Lactobacillus strains used in this study were Lactobacillus acidophilus strain Lacteol (human stool isolate, Lacteol Laboratories, Houdan, France), L. acidophilus CIP 6218 (human vaginal isolate), L. acidophilus NCK 88 (T. R. Klaenhammer, North Carolina University, Raleigh, USA), clinical stool isolates $L$. casei subsp. casei FPC 01.89, and L. casei subsp. rhamnosus FPC 02.90, 03.90 and 04.90. The Lactobacillus plant isolates were FPC 06.90, 07.90 and 08.90. The Lactobacillus animal isolates were: $\mathrm{C} 2$ and $\mathrm{C7}$ (chicken), PA3, PA 19 and PA 47 (pig) (T. R. Klaenhammer). The dairy Lactobacillus strains were: $L$. casei GG (S. L. Gorbach, Tufts University, Boston, USA), L. casei CNRZ 383 (CNRZ, Jouy en Josas, France), $L$. casei subsp. rhamnosus ATCC 7469 and CNRZ 205, $L$. helveticus CNRZ 32 and CNRZ 240, L. delbrueckii subsp. lactis CNRZ 239 and CNRZ 1006, L. delbrueckii subsp. bulgaricus CNRZ 394 and 36. The bacteria were stored in MRS broth (De Man et al., 1960) 
(Biokar, Pantin, France) containing $10 \%$ glycerol $(\mathrm{v} / \mathrm{v})$ at $-80^{\circ} \mathrm{C}$. For the adherence assay, all strains were grown in MRS broth for $18 \mathrm{~h}$ at $37^{\circ} \mathrm{C}$.

Cell culture. The Caco-2 cell line was used between the 65th and 90th passage. Cells were routinely grown in Dulbecco-modified Eagle's minimal essential medium ( $25 \mathrm{~mm}$-glucose) (Eurobio), supplemented with $20 \%(\mathrm{v} / \mathrm{v})$ inactivated $\left(30 \mathrm{~min}, 56^{\circ} \mathrm{C}\right)$ fetal bovine serum (Boehringer) and $1 \%(\mathrm{w} / \mathrm{v})$ non-essential amino acids (Eurobio). For assays, monolayers of Caco-2 cells were prepared on glass coverslips which were placed in six-well Corning tissue culture plates. Cells were seeded at a concentration of $4 \times 10^{4}$ cells $\mathrm{cm}^{-2}$. All experiments and maintenance of cells were carried out at $37^{\circ} \mathrm{C}$ in a $10 \% \mathrm{CO}_{2} / 90 \%$ air atmosphere. The culture medium was changed daily. Unless otherwise stated, cultures were used at post-confluence after $15 \mathrm{~d}$ of culture. To determine the number of Caco- 2 cells in a monolayer, cells were trypsinized for $10 \mathrm{~min}$ at $22{ }^{\circ} \mathrm{C}$ and counted using a haemocytometer.

Adhesion assay. The adhesion of Lactobacillus strains to Caco- 2 cells was examined using an assay previously described for ETEC adhesion (Darfeuille-Michaud et al., 1990). Briefly, the Caco-2 monolayers were washed twice with phosphate-buffered saline (PBS) $(138 \mathrm{~mm}-\mathrm{NaCl}$, $3 \mathrm{mM}-\mathrm{KCl}, 6 \mathrm{mM}-\mathrm{Na}_{2} \mathrm{HPO}_{4}, 1.5 \mathrm{mM}-\mathrm{KH}_{2} \mathrm{PO}_{4}$ ). For each adhesion assay, $0.5 \mathrm{ml}$ Lactobacillus suspension (bacteria with spent broth culture supernatant) was mixed with cell-line culture medium $(0.5 \mathrm{ml})$, and added to each well of the tissue culture plate, which was then incubated at $37{ }^{\circ} \mathrm{C}$ in $10 \% \mathrm{CO}_{2} / 90 \%$ air. The final concentration of bacteria was 2 or $4 \times 10^{8}$ bacteria ml ${ }^{-1}$ as indicated. After incubation (times indicated in each experiment), the monolayers were washed five times with sterile PBS, fixed with methanol, Gram-stained, and examined microscopically under oil immersion. Each adhesion assay was conducted in duplicate with cells from three successive passages. For each glass coverslip monolayer, the number of adherent bacteria was counted in 20 random microscopic areas. Adhesion of Lactobacillus was expressed as the number of bacteria adhering to 100 Caco- 2 cells.

Treatments of bacteria and spent culture supernatant. To characterize the bacterial determinants involved in Lactobacillus adhesion, bacteria with spent broth culture supernatant, bacteria alone or spent broth culture supernatant alone were subjected to various treatments. Bacterial cells and spent broth culture supernatant were separated by centrifugation. Trypsin, pronase and chemical products used were obtained from Sigma.

The bacterial suspension was incubated with Caco-2 cells in the presence of EGTA $(20 \mathrm{mM})$. Where indicated, after incubation of monolayers with Lactobacillus, cells were washed five times with EGTA (20 mM) in PBS.

Bacterial cells alone or spent broth culture supernatant alone were heated to $60^{\circ} \mathrm{C}$ or $100{ }^{\circ} \mathrm{C}$ in a water bath for $30 \mathrm{~min}$ and cooled by immersion in an ice-bath. Bacterial cells alone or spent broth culture supernatant alone were incubated with trypsin $\left(2.5 \mathrm{mg} \mathrm{m}^{-1}\right)$ or pronase $\left(2.5 \mathrm{mg} \mathrm{m}^{-1}\right)$ for $60 \mathrm{~min}$ at $37^{\circ} \mathrm{C}$; trypsin and pronase were inactivated by adding inactivated $\left(30 \mathrm{~min}, 56^{\circ} \mathrm{C}\right)$ fetal bovine serum (Boehringer). The bacteria were preincubated with $50 \mathrm{~mm}$-metaperiodate for 30 minutes, centrifuged, washed in PBS and resuspended in spent culture supernatant at $4 \times 10^{8}$ bacteria $\mathrm{ml}^{-1}$. Bacterial viability was determined after each treatment. Only heating to $100^{\circ} \mathrm{C}$ killed the lactobacilli. Adhesion inhibition by simple sugars was determined by adding D-mannose, L-fucose or D-galactose to the assay (100 mM, final concentration).

Scanning electron microscopy. Cells for scanning electron microscopy were grown on glass coverslips. After the bacterial adhesion assay, the cells were fixed with $2.5 \%(\mathrm{v} / \mathrm{v})$ glutaraldehyde in $0.1 \mathrm{M}$-sodium phosphate buffer ( $\mathrm{pH} \mathrm{7.4)}$ ) $1 \mathrm{~h}$ at room temperature. After washing with phosphate buffer, cells were post-fixed for $30 \mathrm{~min}$ with $2 \%(\mathrm{w} / \mathrm{v})$ $\mathrm{OsO}_{4}$ in the same buffer, washed three times with the same buffer, dehydrated in a graded series $(30 \%$ to $100 \%)$ of ethanol and passaged in a graded series $(50 \%$ to $100 \%)$ of amyl acetate. Cells were dried in a critical-point dryer (Balzers CPD030), and coated with gold. The specimens were then examined with a Jeol JSM $25 S$ scanning electron microscope.

Indirect immunofluorescence. Unpermeabilized Caco-2 cell monolayers on glass coverslips were used for the indirect immunofluorescence study. Cells were fixed for $10 \mathrm{~min}$ at room temperature in $3.5 \%$ $(w / v)$ paraformaldehyde in PBS. Immunoreactivity of sucrase-isomaltase, a brush-border-associated hydrolase characteristic of differentiated intestinal cells (Semenza, 1986), was detected with polyclonal rabbit antibodies against sucrase-isomaltase purified from Caco-2 cells (Trugnan et al., 1987) obtained from Dr Alain Zweibaum (INSERM U 178, Villejuif, France) and anti-rabbit fluorescein-coupled sheep antiglobulins (Institut Pasteur Production, Paris, France).

\section{Results}

\section{Adhesion of lactobacilli to Caco-2 cells}

Twenty-five Lactobacillus strains were examined for their ability to adhere to cultured Caco- 2 cells (Table 1 ). The ability of the Lactobacilli to adhere to the Caco-2 cells in vitro varied considerably between strains. Low attachment to the differentiated Caco- 2 cells was observed with the human stool clinical isolates, the $L$. acidophilus NCK 88, the human vaginal strain CIP 6218, the Lactobacillus plant isolates, the Lactobacillus animal isolates C2, PA3, PA47, and the dairy Lactobacillus ATCC 7469, CNRZ 36, 205, 383, 394, and 1006. High attachment was observed with the human stool isolate $L$. acidophilus strain LB and the strains CNRZ 32, 239 and 240. Moderate attachment was observed with $L$. casei strain GG and L. acidophilus strains C7 and PA19. However, to discriminate between calcium-dependent and calcium-independent adhesion of strains LB, GG, C2, C7, PA3, PA19, PA47, CNRZ 32, 239 and 240, we studied the attachment of strains after washing with EGTA. The rinses with EGTA had no significant effect on the adherence of strains LB, GG, C2, PA3 and PA19 and it decreased significantly the attachment of strains CNRZ 32, 239, 240, PA47 and C7. This result showed that among the adhering lactobacilli tested here, only the human L. acidophilus strain LB, the chicken isolate strain C2, the pig isolates strains PA3 and PA19 and the $L$. casei strain GG strain had a high calcium-independent binding capacity to differentiated Caco- 2 cells in culture.

\section{Characteristics of Lactobacillus adhesion}

To characterize the bacterial components involved in Lactobacillus adhesion, we did experiments using the highly adhering strain $L$. acidophilus LB. The LB strain showed diffuse adhesion to Caco-2 cells (Fig. 1a). As observed in ultrathin sections of the post-confluent monolayer the adhesion appeared to occur at the brush 
Table 1. Adhesion of lactobacilli to Caco-2 cells in culture. Determination of calciumdependent and independent binding

\begin{abstract}
Adhesion assay of lactobacilli strains (final concentration $4 \times 10^{8}$ bacteria $\mathrm{ml}^{-1}$, with spent culture broth) to Caco-2 cells was monitored after $1 \mathrm{~h}$ at $37^{\circ} \mathrm{C}$ in $10 \% \mathrm{CO}_{2} / 90 \%$ air. Mean number of Lactobacilli adhering to the cell monolayer per 100 cells in two identical adhesion assays run in parallel. Twenty randomized microscopic fields per cover slip were counted. Each adherence assay was conducted in duplicate with cells from three successive passages (70-80th cell passages: variation in reproductibility of adhesion less than $5 \%$ from each three cell passages of Caco- 2 cells). Numbers in parentheses indicate standard deviations. Statistical analysis was performed using Student's $t$ test.
\end{abstract}

\begin{tabular}{|c|c|c|c|}
\hline \multirow[b]{2}{*}{ Strains } & \multicolumn{2}{|c|}{ Adhering bacteria } & \multirow{2}{*}{$\begin{array}{l}\text { Reduction in } \\
\text { adhesion }(\%)\end{array}$} \\
\hline & Without EGTA & $20 \mathrm{mM}-\mathrm{EGTA}$ & \\
\hline \multicolumn{4}{|l|}{ Lactobacillus human isolates } \\
\hline L. acidophilus LB & $210(15)$ & $175(20)^{*}$ & 17 \\
\hline L. acidophilus CIP 6218 & $13(4)$ & ND & - \\
\hline L. acidophilus NCK 88 & $8(2)$ & ND & - \\
\hline \multicolumn{4}{|l|}{ Lactobacillus clinical isolates } \\
\hline L. casei subsp. casei FPC 01.89 & $19(7)$ & ND & - \\
\hline L. casei subsp. rhamnosus FPC 02.90 & $36(12)$ & ND & - \\
\hline L. casei subsp. rhamnosus FPC 03.90 & $17(6)$ & ND & - \\
\hline L. casei subsp. rhamnosus FPC 04.90 & $48(11)$ & ND & - \\
\hline \multicolumn{4}{|l|}{ Lactobacillus plant isolates } \\
\hline FPC 06.90 & $5(2)$ & ND & - \\
\hline FPC 07.90 & $4(2)$ & ND & - \\
\hline FPC 08.90 & $7(3)$ & ND & - \\
\hline \multicolumn{4}{|l|}{ Lactobacillus animal isolates } \\
\hline L. acidophilus $\mathrm{C} 2$ & $43(11)$ & $40(10)^{*}$ & 7 \\
\hline L. acidophilus $\mathrm{C} 7$ & $150(12)$ & $88(10) \dagger$ & 41 \\
\hline L. acidophilus $\mathrm{PA} 3$ & $66(12)$ & $63(12)^{*}$ & 4 \\
\hline L. acidophilus PA19 & $92(9)$ & $85(15)^{*}$ & 8 \\
\hline L. acidophilus PA47 & $45(5)$ & $15(2) \dagger$ & 67 \\
\hline \multicolumn{4}{|l|}{ Dairy Lactobacillus } \\
\hline L. casei $\mathrm{GG}$ & $125(15)$ & $105(10)^{*}$ & 16 \\
\hline L. casei subsp. rhamnosus ATCC 7469 & $6(2)$ & ND & - \\
\hline L. casei subsp. rhamnosus CNRZ 205 & $5(2)$ & ND & - \\
\hline L. casei CNRZ 383 & $3(1)$ & ND & - \\
\hline L. casei CNRZ 36 & $6(3)$ & ND & - \\
\hline L. helveticus CNRZ 32 & $200(21)$ & $40(15) \dagger$ & 80 \\
\hline L. helveticus CNRZ 240 & $215(27)$ & $35(15) \dagger$ & 84 \\
\hline L. delbrueckii subsp. lactis CNRZ 239 & $190(20)$ & $90(19) \dagger$ & 53 \\
\hline L. delbrueckii subsp. lactis CNRZ 1006 & $17(7)$ & ND & - \\
\hline L. delbrueckii subsp. bulgaricus CNRZ 394 & $55(7)$ & ND & - \\
\hline
\end{tabular}

* No significant difference from control.

$\dagger P<0.01$.

ND, not done

border of the cell monolayer (Fig. 1 b). Since spent culture supernatant of $L$. acidophilus LB contains lactic acid that could alter the brush border integrity we have observed by scanning electron microscopy that bacterial attachment occurs without cell damage (Fig. 1c).

The kinetics of adhesion of the L.acidophilus strain LB to differentiated Caco- 2 cells was determined using a fixed number of monolayer cells $\left(4.5 \times 10^{5}\right.$ cells $)$ and bacteria $\left(2 \times 10^{8}\right.$ c.f.u. $\left.\mathrm{ml}^{-1}\right)$. Cover slips were washed and stained after $15,30,45,60,90$ and $120 \mathrm{~min}$ incubation. Zero time controls consisted of monolayers to which bacteria were added and then immediately removed. The results of these experiments are presented in Fig. 2. For diffuse adhesion onto Caco-2 cells, maximum adherence occurred within $90 \mathrm{~min}$ and remained stable until the end of the time interval examined.

In an attempt to characterize the adhesin of $L$. acidophilus LB further, we treated the bacteria or the spent broth culture supernatant with various agents (Table 2). A highly significant loss of adhesion was observed when the spent broth was discarded or when it was replaced by fresh bacterial culture medium. These results strongly suggest that a secretory component in the 

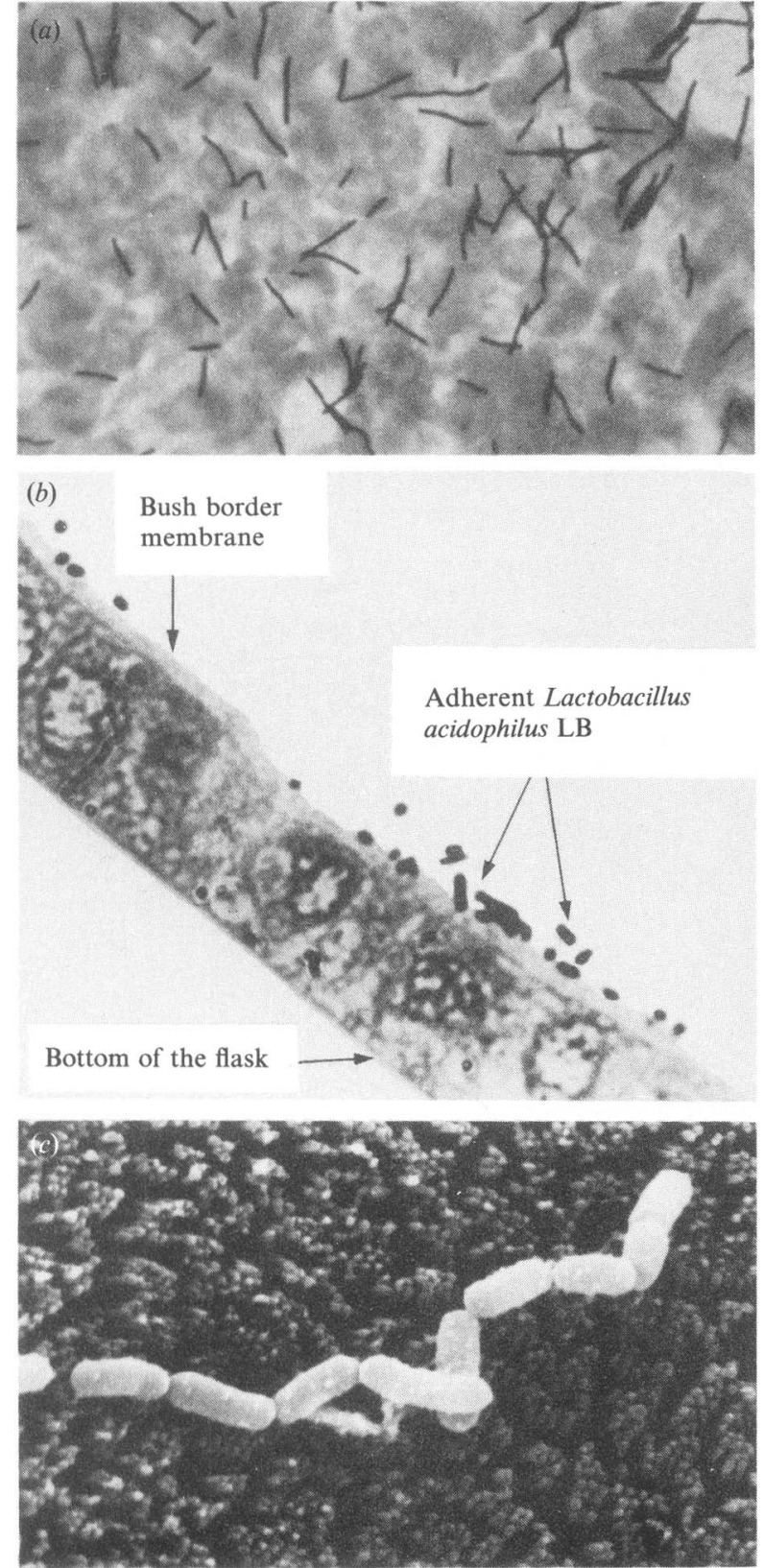

Fig. 1. Adherence of the human stool isolate Lactobacillus acidophilus LB to differentiated Caco-2 cells. (a) Light microscopy after Gramstaining; $(b)$ ultrathin sections of post-confluent monolayer fixed in $3 \%$ glutaraldehyde and embedded in Epon for light microscopic examination of sections perpendicular to the bottom of the flask; (c) scanning electron micrograph of Caco-2 cell monolayers colonized by Lactobacillus LB.

spent broth was involved in adhesion of the L. acidophilus strain LB. Treatment of the spent broth with trypsin or pronase almost totally abolished the adhesiveness of $L$. acidophilus LB. This strongly suggests that the adhesion of strain LB is mediated by a proteinaceous component of bacterial origin in the spent culture broth. Trypsin

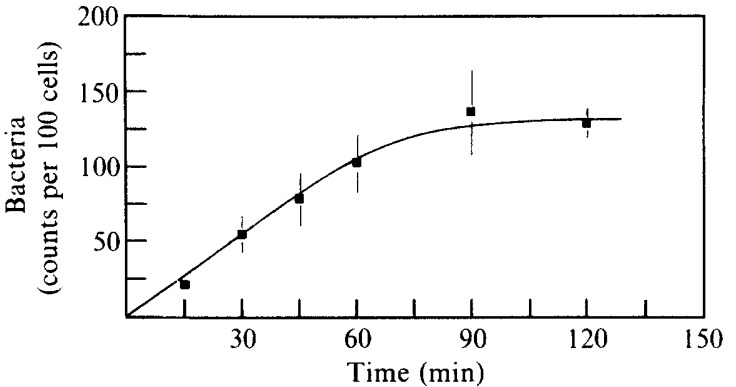

Fig. 2. Adherence time-course of the human stool isolate Lactobacillus acidophilus LB (final concentration $2 \times 10^{8}$ bacteria $\mathrm{ml}^{-1}$ ) to differentiated Caco- 2 cells. Each adherence assay was conducted in duplicate in three successive cell passages. Horizontal bars indicate standard deviations.

treatment of bacteria alone, without treatment of the spent culture broth, did not modify adhesion. A highly significant decrease in adhesion was observed after metaperiodate treatment of bacteria alone, indicating that carbohydrates may be involved in the interaction between the cell-surface component and the adhesionpromoting extracellular protein. The binding of $L$. acidophilus LB was not affected after heating the spent broth or the bacteria to $100^{\circ} \mathrm{C}$. Heating to $100{ }^{\circ} \mathrm{C}$ killed the bacteria. The addition of simple sugars such as Dmannose, L-fucose and D-galactose had no effect on the adhesion of strain LB (Table 2).

\section{Expression of Lactobacillus binding sites during differentiation of Caco-2 cells}

The effect of cellular differentiation was examined by measuring $L$. acidophilus LB adhesion to Caco-2 cells grown for different periods over $15 \mathrm{~d}$. Adhesion was related to the age of the Caco-2 cell culture (Fig. 3). The state of the intestinal differentiation was evaluated by indirect immunofluorescence using antibody directed against the apical differentiation marker sucrase-isomaltase. After $5 \mathrm{~d}$ culture, the proportion of positive sucraseisomaltase immunoreactivity on the cells was estimated to be less than $4 \%$ (Fig. $3 b$ ), indicating that a small proportion of the cells were differentiated. Immunoreactivity increased during subsequent days in culture (Fig. $3 c, d)$; after $15 \mathrm{~d}, 90 \%$ of the Caco-2 cells were differentiated (Fig. $3 d$ ). Lactobacillus binding developed in parallel with the appearance of the differentiation marker (Fig. $3 a$ ). No adhesion of strain LB occurred on the surface of the Caco-2 cells during the first days of culture (undifferentiated cells). Bacterial binding appeared by day 9 and increased subsequently. These results indicate that Lactobacillus interacts with cultured human intestinal cells at cellular sites expressed in the brush border during the differentiation process of Caco-2 cells. 
Table 2. Effects of treatments of bacteria or the spent culture supernatant of strain L. acidophilus $L B$ on adhesion to Caco-2 cells

Adhesion assay of strain LB (final concentration $4 \times 10^{8}$ bacteria $\mathrm{ml}^{-1}$ ) was monitored after $1 \mathrm{~h}$ at $37{ }^{\circ} \mathrm{C}$ in $10 \% \mathrm{CO}_{2} / 90 \%$ air. Mean number of lactobacilli adhering to the cell monolayer per 100 cells in two identical adhesion assays run in parallel. Twenty randomized microscopic fields per cover slip were counted. Each adhesion assay was conducted in duplicate in three successive cell passages. Number in parentheses indicate standard deviations. The control was $L$. acidophilus strain LB in presence of spent culture broth. Statistical analysis was done with the Student's $t$ test.

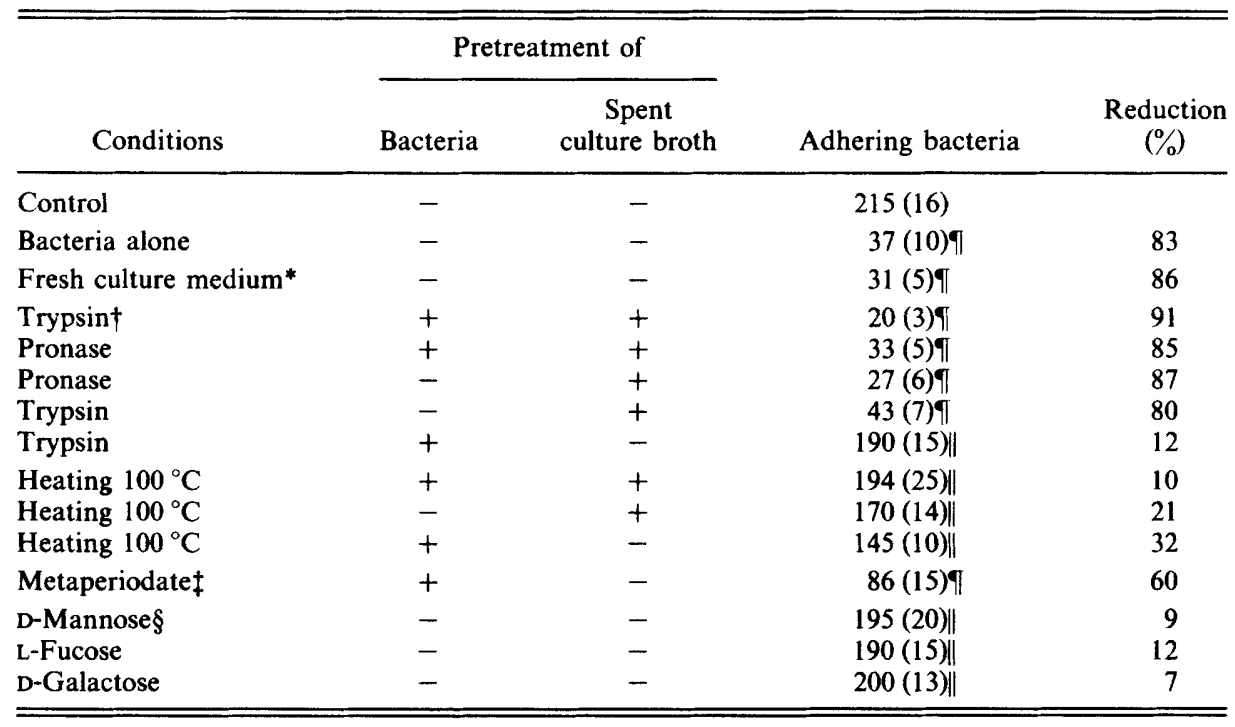

* To determine the presence of adhesins secreted by the bacteria in the spent culture supernatant, it was replaced by a fresh culture medium before adhesion assay.

+ Trypsin $\left(2.5 \mathrm{mg} \mathrm{ml}^{-1}\right)$ or pronase $\left(2.5 \mathrm{mg} \mathrm{m}^{-1}\right)$ treatments for $60 \mathrm{~min}$ at $37^{\circ} \mathrm{C}$; trypsin and pronase were inactivated by adding inactivated $\left(30 \mathrm{~min}, 56^{\circ} \mathrm{C}\right)$ fetal calf serum.

$\ddagger$ Bacteria were preincubated with $50 \mathrm{mM}$-metaperiodate for $30 \mathrm{~min}$, centrifuged, washed in PBS and resuspended in spent culture supernatant.

$\S$ Potential inhibitors were added separately to yield final concentrations of $100 \mathrm{mM}$.

$\|$ No significant difference.

I $P<0.01$.

\section{Discussion}

The mechanism by which Lactobacilli adhere to human intestinal cells remains unknown, but investigation of the mechanism of bacterial adhesion would be greatly facilitated by a suitable cell culture model. Ideally, isolated enterocytes could be used, but unfortunately human intestinal tissue is not readily available. Moreover, the poor viability of isolated human enterocytes and variations between different enterocyte donors have given rise to rather variable results from bacterial adhesion studies in vitro (Darfeuille-Michaud et al., 1990). In the experiments reported here, we used the human intestinal cell line Caco-2, a well-characterized cellular model established from a human colonic adenocarcinoma by Fogh et al. (1977). In culture, this cell line spontaneously develops characteristics of mature enterocytes with functional brush border microvilli and apical hydrolases (Pinto et al., 1983; Hauri et al., 1985). Caco-2 was used extensively in studies on the organization and function of human intestinal cells (reviewed by Zweibaum et al., 1991). The advantages of Caco cells are that they express morphological and functional differentiation in vitro and show characteristics of mature enterocytes. The cells form two clearly distinguishable domains; an apical membrane and a basolateral membrane separated by tight junctions (Simon \& Fuller, 1985). With different protein and lipid compositions, these domains are strikingly different in ultrastructure. For example, the apical surface (brush border) contains peptidases and disaccharidases (Hauri et al., 1985; Pinto et al., 1983), the basolateral domain contains several peptide receptors involved in the control of intestinal hydroelectrolytic secretion (Laburthe \& Amiranoff, 1990 ), and the tight junctions contain specific proteins. These cells are thought to be a convenient model for enterocytes and make an excellent model to study the cell biological processes of adhesion and bacterial invasion. 


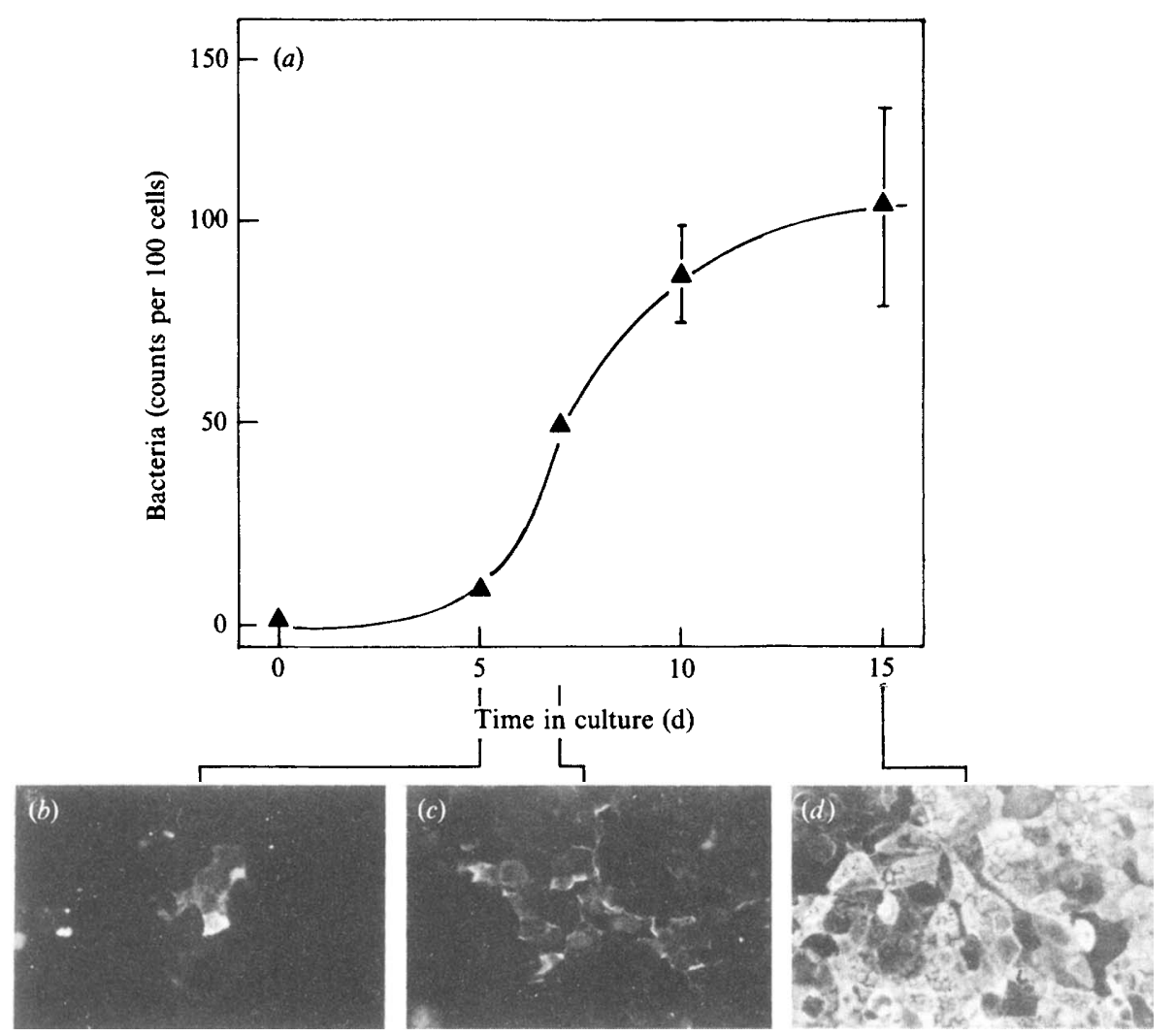

Fig. 3. Change in adhesion of Lactobacillus acidophilus LB to Caco-2 cells as a function of differentiation. (a) Day-course of Lactobacillus adhesion; $(b, c, d)$ immunofluorescent staining with anti-human-sucrase-isomaltase antibody. Adhesion assay of strain LB (final concentration $2 \times 10^{8}$ bacteria $\mathrm{ml}^{-1}$ ) was monitored after $1 \mathrm{~h}$ at $37{ }^{\circ} \mathrm{C}$ in $10 \% \mathrm{CO}_{2} / 90 \%$ air. Each adherence assay was conducted in duplicate using cells from three successive passages (70-73). Horizontal bars indicate standard deviations.

Moreover, they were recently used for studying humanspecific bacteria for which animal models do not exist. Indeed, Caco-2 cells bind Listeria monocytogenes (Gaillard et al., 1987; Mounier et al., 1990), enterotoxigenic Escherichia coli (ETEC) producing CFA I, CFA II, CFA III, antigen 2230 adhesin factors (Darfeuille-Michaud et al., 1990), diffusely adhering (DAEC) (Kerneis et al., 1991) and enteropathogenic Escherichia coli (EPEC) (Knutton et al., 1989), Salmonella typhimurium (Finlay \& Falkow, 1990; Gahring et al., 1990), Vibrio cholerae (Panigrahi et al., 1990), Cryptosporidium parvum (Flanigan et al., 1991) Entamoeba histolytica (Rigothier et al., 1991), rotavirus (Svensson et al., 1991) and reovirus (Ambler \& Mackay, 1991). This cell line provides, postconfluence, a uniform population of differentiated cells that can be used under defined conditions in a simple reproducible assay to quantify adherent bacteria.

The ability of Lactobacilli to adhere to the differentiated Caco- 2 cells varied considerably between strains, which showed that adhesive properties are not a universal feature of Lactobacillus. Particularly, the results showed that among the twenty-five Lactobacillus strains screened seven lactobacilli of different origin adhered well to Caco- 2 cells. As indicated by Kleeman \& Klaenhammer (1982), di- and trivalent cations may act by providing an ionic bridge between surfaces of bacteria and epithelial cells and play a role in many adherence systems. These authors have demonstrated that enhanced adhesion of lactobacilli to intestinal cells was promoted by the divalent cation calcium. This adhesion is distinct from the adhesion occurring in the absence of the cations. Among the adhering strains tested in the present study, three possess calcium-independent capabilities; in particular, a high level of calcium-independent binding was expressed by the human stool isolate L. acidophilus LB.

The adhesion of Lactobacillus strain LB to Caco- 2 cells appeared to be mediated by two components: a cellsurface component and an extracellular factor. The cellsurface determinant of strain LB did not appear to be proteinaceous. This is of interest, since it is generally accepted that the non-proteinaceous cell-wall component lipoteichoic acid is involved in the adhesion of some Gram-positive bacteria (Araki \& Ito, 1989; Chan et al., 
1985). The nature of the cell-surface determinant of strain LB needs to be further characterized and compared with determinants expressed on the bacterial cell surface of other intestinal adherent Lactobacilli, such as BG2FO4 (Kleeman \& Klaenhammer, 1982; Hood \& Zotola, 1989), the human-uroepithelial-adhering GR strains (Chan et al., 1985; Reid \& Sobel, 1987) and the strains of animal origin L. fermentum 737 (Conway \& Kjelleberg, 1989) and L. fermentum 104 (Henriksson et al., 1991). Trypsin and pronase treatments of the spent culture supernatant of strain LB greatly decreased the adhesion of strain LB, which suggested that the extracellular component was proteinaceous. A similar result has been reported in two comprehensive and elegant studies with the mouse $L$. fermentum strain 737 (Conway \& Kjelleberg, 1989) and porcine strain 104 (Henriksson et al., 1991) that adhere to mouse and porcine gastric squamous epithelia, respectively. Altogether, these results suggest that the mechanism of adhesion of Gram-positive bacteria to human intestinal cells may be quite different from that of Gram-negative bacteria, which involves fimbrial or membrane adhesins (De Graaf, 1990). Work is in progress to isolate and characterize the extracellular adhesion-promoting determinant of the human Lactobacillus.

In Caco- 2 cells, the time-course of the differentiation process, with undifferentiated exponentially dividing cells which differentiate when the cells stop dividing (Zweibaum et al., 1990), closely mimics the situation found in the small intestine. Since the differentiation of Caco-2 cells, which form tight monolayers, occurs spontaneously in culture (Pinto et al., 1983), these cells represent attractive models for the study of the relationship between the state of differentiation and the $L$. acidophilus binding sites. The lack of binding to the undifferentiated Caco- 2 cells during the first days of culture and the progressive increase in bacterial binding with increased duration of culture strongly suggest that the expression of specific Lactobacillus binding sites is related to the differentiation status of the intestinal cells. We previously noticed that the human enterocytic receptors for the diffusely adhering $E$. coli (DAEC) C1845 were also expressed during the enterocytic differentiation process of the HT-29 and Caco-2 cell lines in culture (Kerneis et al., 1991). The nature of the intestinal human Lactobacillus binding sites remains to be determined.

This work was supported by a grant INSERM-Industrie no. 88128 . We thank Professor T. R. Klaenhammer (North Carolina University, Raleigh) for the gift of the human and animal lactobacilli strains, Drs S. L. Gorbach and B. R. Goldin (Tufts University, Boston) for the gift of L. casei strain GG, and T. Lambert (Hôpital Saint Michel, Paris, France) for isolating the clinical strains. We thank Dr A. Zweibaum (INSERM U 178, Villejuif, France) for providing us with Caco-2 cells and sucrase-isomaltase antibody; D. Guillaumin (Service Microscopie Electronique. CNRS Raspail Paris VI) for the technical assistance with the electron microscopy study, and Tuomo Karjalainen for his careful reading of the manuscript.

\section{References}

Ambler, L. \& Mackay, M. (1991). Reovirus 1 and 3 bind and internalise at the apical surface of intestinal epithelial cells. Virology 184, 162-169.

ARAKI, Y. \& ITO, E. (1989). Linkage units in cell walls of Gram-positive bacteria. Critical Reviews in Microbiology 17, 121-135.

Chan, R. C. Y., Bruce, A. W. \& ReID, G. (1984). Adherence of cervical, vaginal and distal urethral normal microbial flora to human uroepithelial cells and the inhibition of adherence of gram-negative uropathogens by competitive exclusion. Journal of Urology 131, 596601 .

Chan, R. C. Y., Reid, G., Irvin, R. T., Bruce, A. W. \& Costerton, J. W. (1985). Competitive exclusion of uropathogens from human uroepithelial cells by Lactobacillus whole cells and cell wall fragment. Infection and Immunity 47, 84-89.

Chauvière, G., Coconnier, M. H., Kerneis, S., DarfeuilleMichaud, A., Joly, B. \& Servin, A. L. (1992). Competitive exclusion of diarrheagenic Escherichia coli (ETEC) from enterocytelike Caco-2 cells by heat-killed Lactobacillus. FEMS Microbiology Letters 91, 213-218.

Conway, P. (1988). Lactobacilli: Fact and fiction. In The Regulatory and Protective Role of the Normal Flora, pp. 263-281. Edited by R. Grun, T. Midvedt \& E. Norin. Stockton Press.

CONWAY, P. L., Gorbach, S. L. \& Goldin, B. R. (1987). Survival of lactic acid bacteria in the human stomach and adhesion to intestinal cells. Journal of Dairy Science 70, 1-12.

Conway, P. L. \& KJelleberg, S. (1990). Protein-mediated adhesion of Lactobacillus fermentum strain 737 to mouse stomach squamous epithelium. Journal of General Microbiology 135, 1175-1186.

Darfeuille-Michaud, A., Aubel, D., Chauvière, G., Rich, C., Bourges, M., Servin, A. \& Joly, B. (1990). Adhesion of enterotoxigenic Escherichia coli to the human colon carcinoma cell line Caco-2 in culture. Infection and Immunity 58, 893-902.

De Man, J. C., Rogosa, M. \& Sharp, M. T. (1960). A medium for the cultivation of Lactobacilli. Journal of Applied Bacteriology 23, 130135.

De GraAF, F. K. (1990). Genetics of adhesive fimbriae of intestinal Escherichia coli. Current Topics in Microbiology and Immunology 151, 29-53.

Elo, S., Saxelin, M. \& Salminen, S. (1991). Attachment of Lactobacillus casei strain GG to human colon carcinoma cell line Caco-2: comparison with other dairy strains. Letters in Applied Microbiology 13, 154-156.

FinLAY, B. B. \& FALKow, S. (1990). Salmonella interactions with polarized human intestinal Caco-2 epithelial cells. Journal of Infectious Diseases 162, 1096-1106.

Flanigan, T. P., AJi, T., Marshall, R., Soave, R., Aikawa, M. \& KAETZEL, C. (1991). Asexual development of Cryptosporidium parvum within a differentiated human enterocyte cell line. Infection and Immunity 59, 234-239.

FoGH, J., FoGH, J. M. \& ORfEO, T. (1977). One hundred and twentyseven cultured human tumor cell lines producing tumors in nude mice. Journal of National Cancer Research 59, 221-226.

Gahring, L. C., Hefrron, F., Finlay, B. B. \& Falkow, S. (1990). Invasion and replication of Salmonella typhimurium in animal cells. Infection and Immunity 58, 443-448.

Gaillard, J. L., Berche, P., Mounier, J., Richard, S. \& Sansonetti, J. P. (1987). In vitro model of penetration and intracellular growth of Listeria monocytogenes in the human enterocyte-like cell line Caco-2. Infection and Immunity 55, 2822-2829.

hauri, H. P., Sterchi, E. E., Bienz, D., Fransen, J. A. M. \& MARXER, A. (1985). Expression and intracellular transport to microvillus membrane hydrolases in human intestinal epithelial cells. Journal of Cellular Biology 101, 838-851. 
HenRiksson, A., Szewly, R. \& Conway, P. L. (1991). Characteristics of the adhesive determinants of Lactobacillus fermentum 104. Applied and Environmental Microbiology 57, 499-502.

HoOD, S. K. \& ZoTTOLA, E. A. (1989). An electron microscopic study of the adherence of Lactobacillus acidophilus to human intestinal cells in vitro. Food Microstructure 8, 91-97.

Kernérs, S., Bilge, S., Fourel, V., Chauvière, G., Coconnier, M. H. \& SERVIN, A. L. (1991). Use of purified F1845 fimbrial adhesin to study localization and expression of receptors for diffusely adhering Escherichia coli (DAEC) during enterocytic differentiation of human colon carcinoma cell lines HT-29 and Caco-2 in culture. Infection and Immunity 59, 4013-4018.

Kleeman, E. G. \& K laenhammer, T. R. (1982). Adherence of Lactobacillus species to human fetal intestinal cells. Journal of Dairy Science 65, 2063-2069.

Knutton, S., Baldwin, T., Williams, P. H. \& MCNeish, A. S. (1989). Actin accumulation at sites of bacterial adhesion to tissue culture cells: Basis of a new diagnostic test for enteropathogenic and enterohemorrhagic Escherichia coli. Infection and Immunity 57, 12901298

Laburthe, M. \& Amiranoff, B. (1990). Peptide receptors in intestinal epithelium. In Handbook of Physiology. The Gastrointestinal System, vol. IV, pp. 215-243. Edited by S. J. Schultz, M. Field \& R. A. Frizell. Bethesda, Md: American Physiological Society.

Mounier, J., Ryter, A., Coquis-Rondon, M. \& Sansonetti, P. J. (1990). Intracellular and cell-to-cell spread of Listeria monocytogenes involves interaction with $\mathrm{F}$-actin in the enterocyte-like cell line Caco-2. Infection and Immunity 58, 1048-1058.

Panigrahi, P., Tall, B. D., Russell, R. G., Detolla, L. J. \& Morris, J. G., JR (1990). Development of an in vitro model to study of non-O1 Vibrio cholerae virulence using Caco-2 cells. Infection and Immunity 58, 3415-3424.

Pinto, M., Robine-Leon, S., Appay, M. D., Kedinger, M., Triadou, N., DussaulX, E., Lacroix, B., Simon-Assmann, P., Haffen, K., Fogh, J. \& ZWeIbaum, A. (1983). Enterocyte-like differentiation and polarization of the human colon carcinoma cell line Caco-2 in culture. Biology of the Cell 47, 323-330.
Reid, G., Bruce, A. W., McGroarty, J. A., Cheng, K. J. \& Costerton, J. W. (1990). Is there a role for Lactobacilli in prevention of urogenital and intestinal infection. Clinical Microbiological Reviews 3, 335-344.

REID, G., COOK, R. L. \& BRUCE, A. W. (1987). Examination of strains of Lactobacilli for properties that may influence bacterial interference in the urinary tract. Journal of Urology 138, 330-335.

REID, G. \& SOBEL, J. D. (1987). Bacterial adherence in the pathogenesis of urinary tract infection: a review. Reviews of Infectious Diseases 9 , 470-487.

Rigothier, M. C., Coconnier, M. H., Servin, A. L. \& Gayral, P. (1991). Adhesion of Entamoeba histolytica to the human colon carcinoma cell line, Caco-2. A new in vitro model - scanning electron microscopic study. Infection and Immununity 59, 4142-4146.

Semenza, G. (1986). Anchoring and biosynthesis of stalked brush border membrane proteins: glycosidases and peptidases of enterocytes and renal tubuli. Annual Review of Cellular Biology 2, 255-313

SimON, K. \& FulleR, S. D. (1985). Cell surface polarity in epithelia. Annual Review of Cellular Biology 1, 242-288.

Svensson, L., Finlay, B. B., Bass, D., VonbonsdorfF, C. H. \& GREENBERG, H. B. (1991). Symmetric infection of rotavirus on polarized human intestinal epithelial Caco-2 cells. Journal of Virology 65, 4190-4197.

Trugnan, G., Rousset, M., Chantret, I., Barbat, A. \& Zweibaum, A. (1987). The post-transcriptional processing of sucrase-isomaltase in HT-29 cells is a function of their state of enterocytic differentiation. Journal of Cellular Biology 104, 1199-1205.

Wenneras, C., Holmgren, J. \& Svennerholm, A. M. (1990). The binding of colonization factor antigens of enterotoxigenic Escherichia coli to intestinal cell membrane proteins. FEMS Microbiology Letters. 66, 107--112.

Zweibaum, A., Laburthe, M., Grasset, E. \& Louvard, D. (1991) Use of cultured cell lines in studies of intestinal cell differentiation and function. In Handbook of Physiology. The Gastrointestinal System, vol. IV, pp. 223-255. Edited by S. J. Schultz, M. Field and R. A. Frizell. Bethesda, Md: American Physiological Society. 